\title{
The effect of environmental changes on the efficiency of the PV system
}

\author{
Adeel Saleem ${ }^{1}$, Atif Iqbal ${ }^{2}$, Muhammad Aftab Hayat ${ }^{3}$, Manoj Kumar Panjwani ${ }^{4}$, \\ Fareed Hussain Mangi ${ }^{5}$, Raja Masood Larik ${ }^{6}$ \\ ${ }^{1}$ Department of Electrical Engineering, the University of Lahore, Pakistan \\ ${ }^{2,4}$ School of Renewable Energy \& Clean Energy, North China Electric Power University, China \\ ${ }^{3}$ School of Control \& Computer Engineering, North China Electric Power University, China \\ ${ }^{4,5}$ Department of Energy Systems Engineering, Sukkur IBA University, Pakistan \\ ${ }^{6}$ School of Electrical Engineering, Universiti Teknologi Malaysia Skudai, Malaysia
}

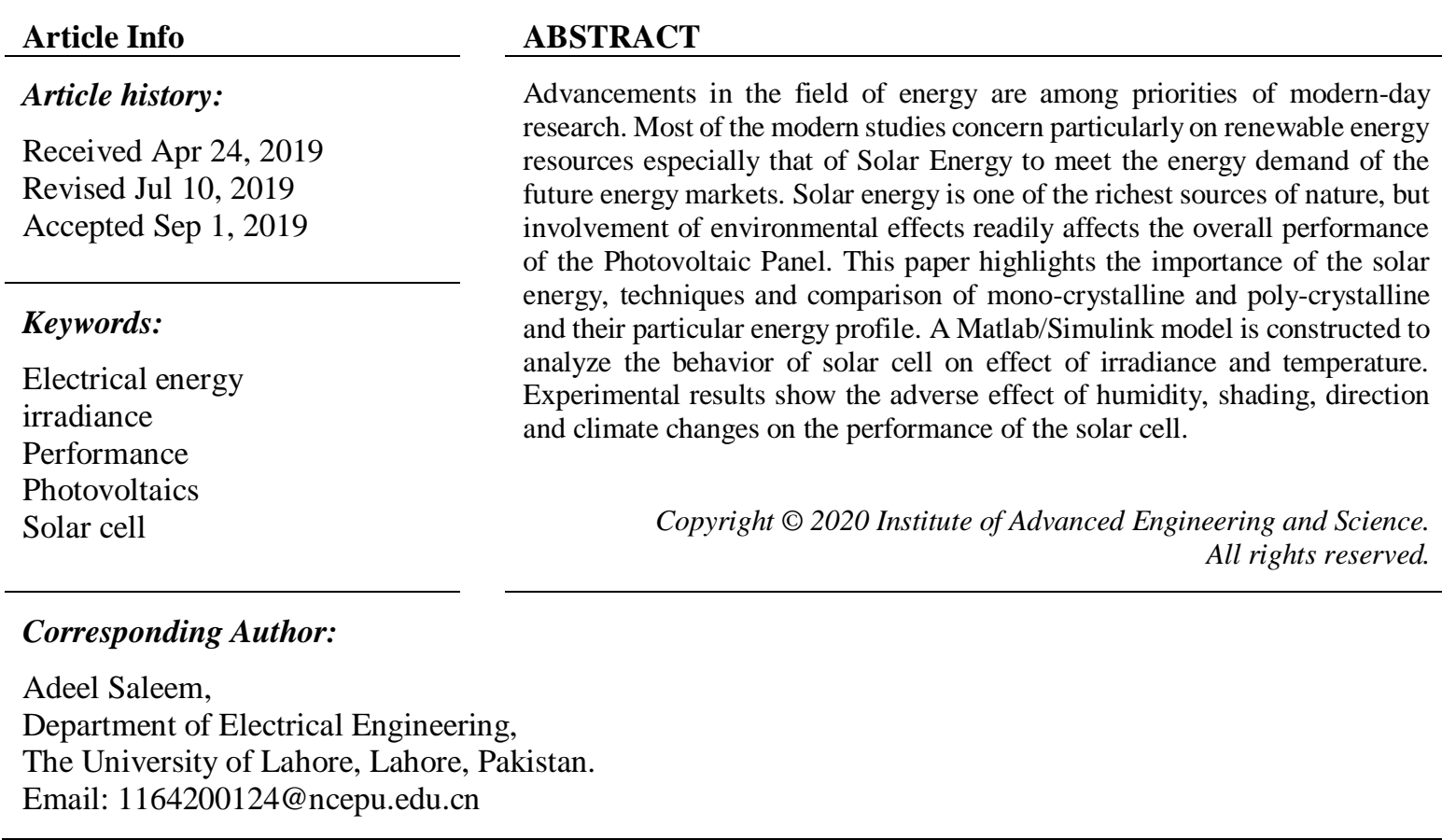

\section{INTRODUCTION}

With increasing population, there is a substitute increase in the demand which majorly include basic demands like food water and shelter with particular technical demand as electrical energy because most of the equipment in the modern household requires electrical energy. The most portion of the current electrical generation is mainly from the fossils that not only are depleting but they subsequently contribute towards polluting the environment.In assuring a green and clean environment there is an urgent need of the renewable energy sources such as tidal energy, wind energy, geothermal, and solar energy [1-3]. Solar energy is one of the important resources on the earth, so it should not be ignored. Photovoltaic Panel is used to convert the solar energy coming from the sun and converts it into useable electrical energy to meet the energy demand of a limited area. Various energy storage techniques are used these days in order to assure supply of the electrical energy in the night time [4-6].

There are two basic techniques for getting the solar energy from the sun and these are active and passive. These two only are the possible ways to capture the solar energy from the sun. Passive solar energy system is used by the ancient people in which they build their houses of clay or stones, which get the energy in form of heat from the sun in day time and keep their houses warm in the dark as shown in Figure 1. So, by this they keep their houses warm throughout the night. Now a day the builders also use the same method for capturing solar energy. Some time by using the thick insulation on the walls, stone flooring, architectural techniques and carefully placed windows are effective methods to get passive solar energy from the sun to keep heat the buildings. 
The second technique of the solar energy is the active solar energy system as shown in Figure 2 which also works on the same principle of the passive solar energy system butt only it uses some form of fluid to absorb the heat from the sun. Most commonly the active solar energy system uses the water as a fluid to absorb the heat from the shining sun. In addition, on the roof a simple solar collector is installed to heat the fluid and then circulate in the whole building to keep it warm.

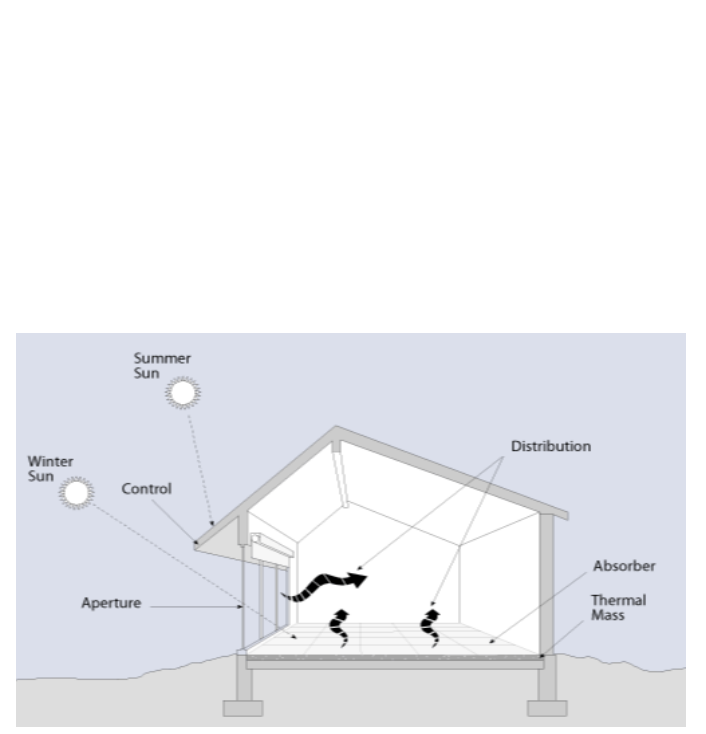

Figure 1. Passive solar technique [7]

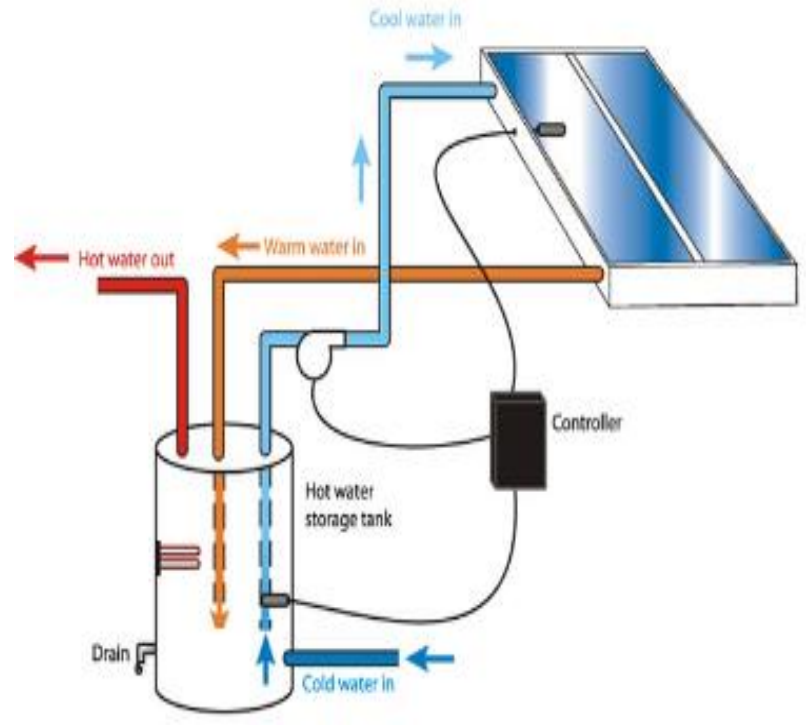

Figure 2. Active solar technique [8]

The PV system includes photovoltaic cells, or solar panels are the modern ways and more involved than the active and passive solar energy systems. They are made of thin silicon sheets and are used to convert solar energy to electrical as shown in Figure 3. The advantage of these sheets is they less in cost and can be easily installed on the roof [9]. Most of the people living such as islands and mountain tops or the remote areas they are using PV system to generate electricity for their houses and this is the best and economical option for them [10].

The solar cells made of different materials and have their own properties. To get the maximum efficiency from the PV system it should be treated as very carefully [11]. There are number of factors which affect the efficiency of the solar cells. Humidity, irradiation, temperature, wind speed, dust are some important factors which affects the performance of the solar cells. To study the effect of all these parameters on the performance of PV system is done here as shown in Figure 4. These factors are known as the environmental effects [12-14]. Some are the other factors which may cause the efficiency of the solar cells such as shading, angle and the load attached to it. So, for the better efficiency of the solar cell these all factors should be studied very carefully.

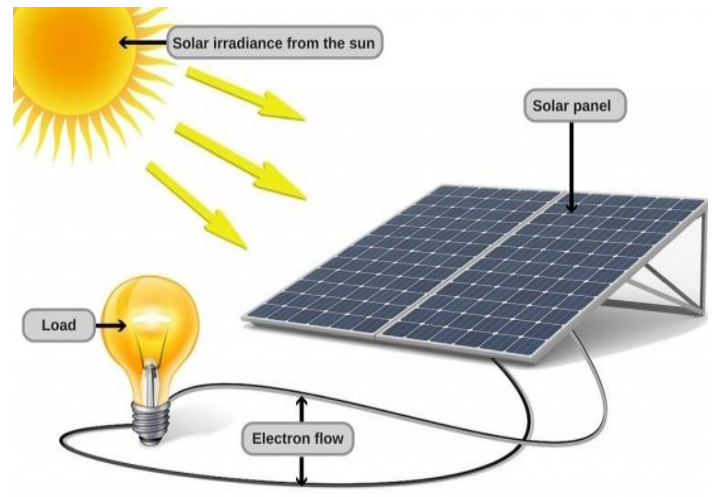

Figure 3. Conversion of solar energy to electrical

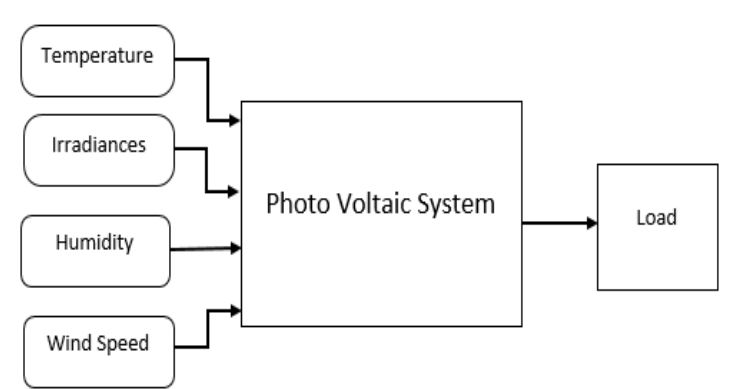

Figure 4. Environmental effects on PV system energy 
To understand the working of simple PV system the equivalent electrical circuit of photovoltaic is shown in Figure 5 [15]. The electrical circuit comprises of different components and parameters as follows [16].

a) $I_{L}$ is equivalent to light generated current source

b) $I_{d}$ is diode current

c) $R_{S h}$ is Shunt Resistance

d) $R_{s}$ is Series Resistance

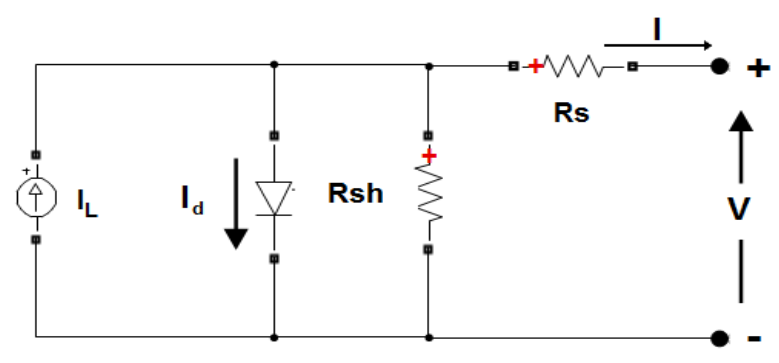

Figure 5. Electrical circuit for the PV cells

To understand the I-V characteristics of single module [17], the equations are given [18].

$$
\begin{aligned}
& \mathrm{I}_{\mathrm{d}}=\mathrm{I}_{0}\left[\exp \left(\frac{\mathrm{V}_{\mathrm{d}}}{\mathrm{V}_{\mathrm{T}}}\right)-1\right] \\
& \mathrm{V}_{\mathrm{T}}=\frac{\mathrm{kT}}{\mathrm{q}} \times \mathrm{nI} \times \text { Ncell }
\end{aligned}
$$

As in equations (1) and (2) $\mathbf{I}_{\mathbf{d}}$ is diode current (A), $\mathbf{V}_{\mathbf{d}}$ is diode voltage (V), $\mathbf{I}_{\mathbf{0}}$ is the diode saturation current (A), $\mathrm{nI}$ is the diode ideality factor, a number close to $1, \mathrm{~K}$ is Boltzmann constant which is equal to1.3806e $e^{-23} \mathrm{~J} . K^{-1}, \mathrm{q}$ is electron charge which is equal to $1.6022 e^{-19} \mathrm{C}$, T is cell temperature $(\mathrm{K})$ and Ncell is the number of cells connected in series in module [19].

\section{DIFFERENT TYPES FOR SOLAR CELL}

There are two major types for the solar cell and these are the mono-crystalline and poly-crystalline and both almost made of silicon crystals [20]. For a PV module these solar cells are connected in series. The size of a PV module decides the capacity of the solar size. Now if these PV modules are further connected together then a PV array is made. As research says the mono crystalline is much better than the other type of solar cell [21]. Following in the Table 1 shows the basic comparison between these two major types of solar cell.

Table 1. Comparison between Mono-Crystalline and Polly-Crystalline

\begin{tabular}{llll}
\hline PV Module type & Mono-crystalline & Poly-crystalline & Thin Film \\
\hline Theoretical efficiency & $25.0 \%$ & $20.4 \%$ & $18.7 \%$ \\
Practical efficiency & $15-20 \%$ & $13-16 \%$ & $9-11 \%$ \\
Area/kW & $6-9 \mathrm{~m}^{2}$ & $8-9 \mathrm{~m}^{2}$ & $10 \mathrm{~m}^{2}$ \\
Warranty & 25 years & 25 years & $10-25$ years \\
Lowest price & $0.75 \$ / \mathrm{w}$ & $0.62 \$ / \mathrm{w}$ & $0.7 \$ / \mathrm{w}$ \\
Temperature resistance & Performance Drops but good & Slightly better & Not good \\
Fill factor & $70-75 \%$ & $70-75 \%$ & $50-60 \%$ \\
\hline
\end{tabular}

\section{PV MODEL SPECIFICATIONS}

A standard PV panel is chosen to study the efficiency of the PV system on the environmental changes. A model is built in the MATLAB/SIMULINK to check the effects of different parameters. In addition to this, a practical is performed and the solar specifications are as under in Table 2 and practical results are summarized in the factors affecting on the PV system. 
In simulation model, we have taken three arrays, which gives combined rated output power of 245 watts. The simulation has been performed and the result of one array is provided in shown in Figure 6. From that, we can analyze the maximum power of array at certain point, when the temperature, irradiances and other parameters are optimal. The sum of voltage and current drawn from all arrays and for individual array is shown in Figure 7.

Table 2. Specification for the Solar Cell

\begin{tabular}{ccc}
\hline Module Type & - & JKM254P-60-I \\
\hline Rated maximal power & $P_{M a x}$ & $245 \mathrm{~W}(0 \sim+3 \%)$ \\
Rated Voltage & $V_{m p}$ & $30.2 \mathrm{~V}$ \\
Open circuit voltage & $V_{O c}$ & $37.4 \mathrm{~V}$ \\
Rated current & $I_{m p}$ & $8.12 \mathrm{~A}$ \\
Short circuit current & $I_{S c}$ & $8.69 \mathrm{~A}$ \\
Maximal series fuse & - & $15 \mathrm{~A}$
\end{tabular}

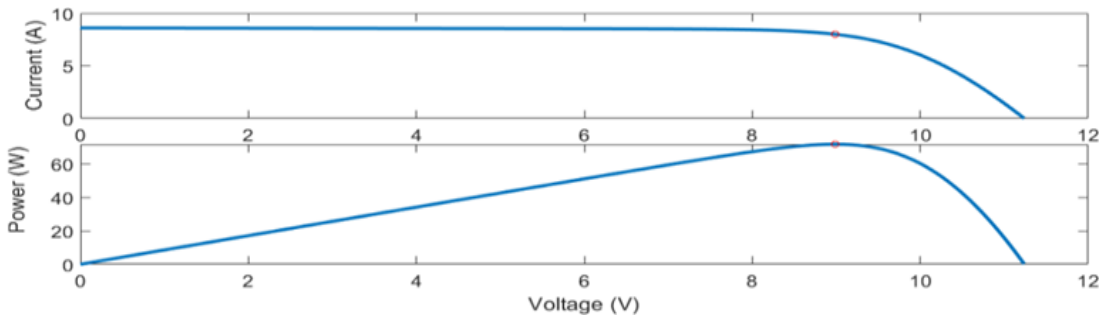

Figure 6. Maximum Power for one Array of 245 watt solar panel

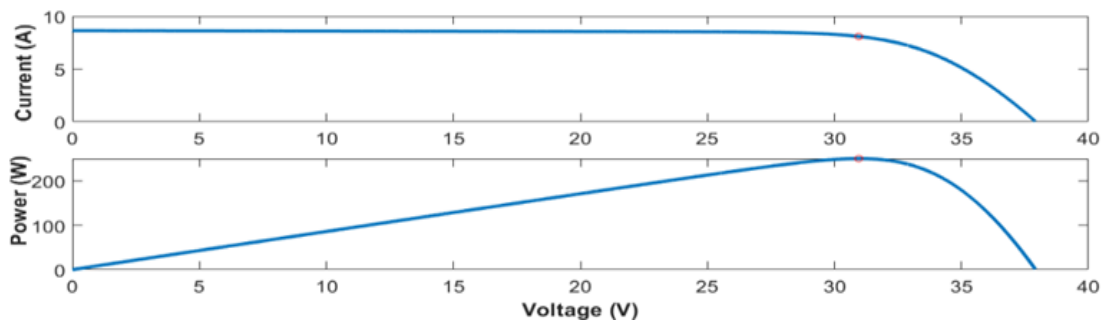

Figure 7. I-V and P-V characteristics for the 245 watts panel

Whereas the I-V and P-V characteristics is shown in Fig 7. To check the performance of the PV system on environmental effects, in this paper provided variable temperature and variable irradiances in Matlab/Simulink model and the results are shown in the factors affecting the efficiency of the PV system.

\section{FACTORS AFFECTING ON THE EFFICENCY OF PV SYSTEM}

To get the maximum efficiency from the PV system these following factors should be considered. There are number of factors affecting the performances and efficiency of the PV system. Some are the environmental factors which have to be maintained for the better results.

\subsection{Effect of the irradiance}

Output power of the PV systems entirely depends upon the irradiations. As the irradiances increases, the output power is maximized. The considered model of PV system is simulated at different irradiances, while keeping the temperature constant. The simulated results of particular model are shown in Figure 8 , which proves the relation of irradiances with output power.

From Figure 8, it is observed that the slight change of irradiance results in increase of output power for PV system. To obtain maximize, optimal power and efficiency, should have to ensure the maximum availability of irradiance. 


\subsection{Effect of the Temperatue}

The PV systems operate at its maximum efficiency, while keeping the conditions standard at $25^{\circ} \mathrm{C}$ temperature and irradiance of $1000 \mathrm{w} / \mathrm{m}^{2}$. By increasing temperature, voltage decreases and current increases. Increasing $1^{\circ} \mathrm{C}$ temperature, the current increases up to $0.05 \%$ while, voltage is decreased by $0.37 \%$, resulting in overall decrease of power by $0.5 \%$ [22-23]. The simulated results of particular model are shown in Figure 9 , which illustrate the behavior of output power with respect to temperature.

The maximum allowable temperature for solar cell is below $80^{\circ} \mathrm{C}$; below this temperature it maintains its efficiency and life. Above this maximum allowable temperature, the efficiency as well as life span of solar cell is affected badly. From above discussions and results one can conclude that, we can tradeoff between temperature and efficiency in such a way to use the better solar material at higher temperature places and vice versa in order to extract economical and optimal output power.
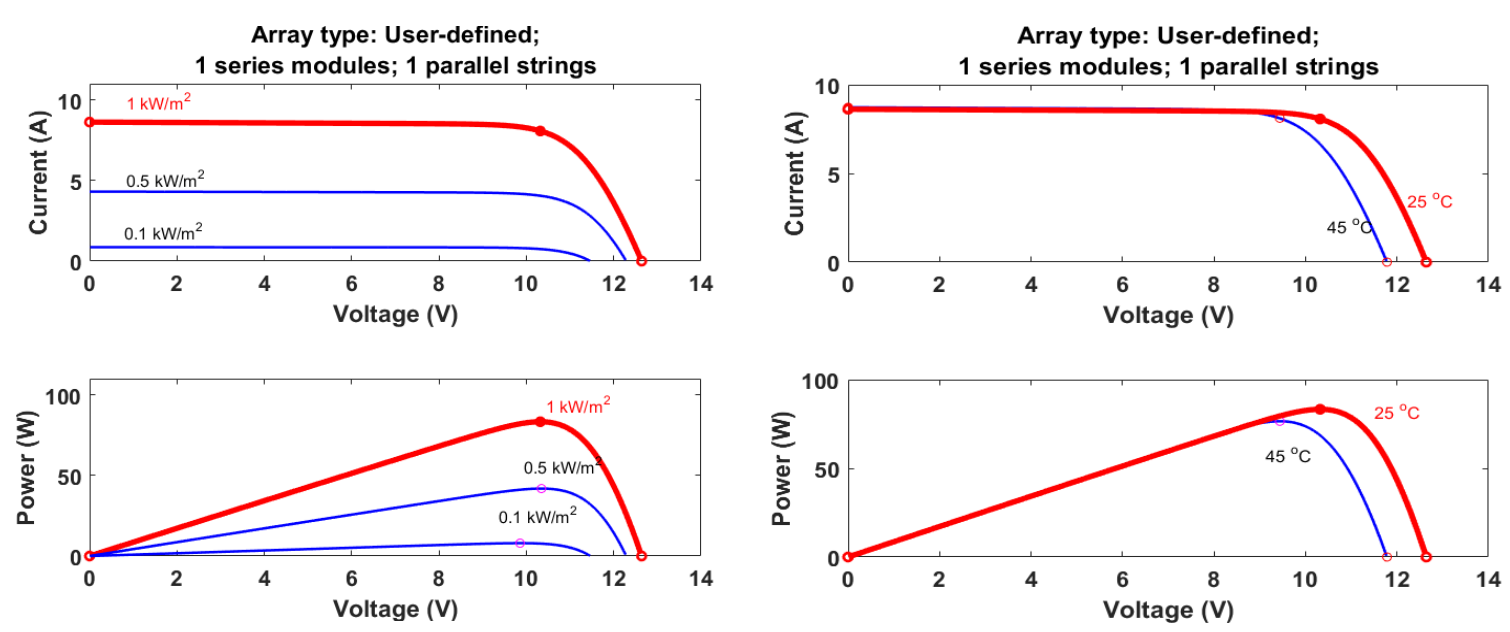

Figure 8. Effect of irradiance on the power output of PV system

Figure 9. Effect of irradiance on the power output of PV system

\subsection{Effect of the Shadow}

The output of the solar cell varies when there is shade on it and depends on the amount of shade. There are two major types of shades which affect the performance of the solar cells.

a) Soft shade

b) Hard shade

While the solar cell is under the soft shade then the current decreases so in the results power decreases. In case of the hard shade the voltages drop badly and in results power decreases. The effects of different shadings such as partially, corner, bottom and no shadings are analyzed to practical PV system and the results are shown in Table 3.

The shaded effect clearly shows that it drops the output power for the PV system as shown in Figure 10. So, the placement of the PV system should be in this manner that it should not be under any shadow for the maximum time.

\subsection{Effect of the humidity}

Humidity is the moisture content in the air. Different areas have different humidity according to their climate conditions so this factor has its considerable impacts on output power. The output will vary due to the change of humidity. If the humidity is more in the atmosphere then defiantly it decreases the intensity of the sunlight which falls on the solar panel, so in results it affects the efficiency of the PV system. The effect of the humidity is summarized in the Table 4 on a fix temperature environment of $32{ }^{\circ} \mathrm{C}$. It shows that the increase in humidity put an effect on the performance of PV system.

\subsection{Effect of the Direction}

One of the major factors affecting on the performance of the efficiency of the solar cell is the best and suitable direction. The Table 5 shows the output current and the voltage on the different direction of the solar cell for $250 \mathrm{~W}$ PV model. The current changes when you change the direction of the solar cell. So, the direction of the solar cell should be according to the Azimuth angle to get the maximum power. 
Table 3. Shading Effect on the Performance of PV System

\begin{tabular}{|c|c|c|c|c|}
\hline Irradiation & Temperature & $\mathrm{Pm}$ & $\mathrm{Um}$ & $\mathrm{Im}$ \\
\hline$W / m 2$ & ${ }^{0} \mathrm{C}$ & $W$ & V & $A$ \\
\hline \multicolumn{5}{|c|}{ Not shaded } \\
\hline 443 & 31.5 & 75.5 & 27.9 & 2.706 \\
\hline 533 & 32.6 & 99.94 & 27.4 & 3.246 \\
\hline 650 & 33 & 138.58 & 27.3 & 4.967 \\
\hline 682 & 35.8 & 141.94 & 27 & 5.257 \\
\hline \multicolumn{5}{|c|}{ Shaded in the middle (by person) } \\
\hline 400 & 30 & 47.58 & 31.7 & 1.501 \\
\hline 427 & 31 & 50.44 & 31.4 & 1.643 \\
\hline 505 & 32 & 52.6 & 31.2 & 1.686 \\
\hline 600 & 36.8 & 70.65 & 30.7 & 2.25 \\
\hline \multicolumn{5}{|c|}{ Shaded in the corner } \\
\hline 400 & 31.7 & 61.4 & 18.2 & 3.374 \\
\hline 440 & 32 & 66.04 & 18.1 & 3.669 \\
\hline 530 & 33 & 83.59 & 18 & 4.593 \\
\hline 677 & 35.9 & 92.89 & 17.5 & 5.308 \\
\hline \multicolumn{5}{|c|}{ Shaded in the bottom } \\
\hline 378 & 32 & 50.73 & 18.7 & 2.803 \\
\hline 480 & 32.7 & 61.02 & 18.2 & 3.276 \\
\hline 506 & 34 & 61.3 & 18.1 & 3.358 \\
\hline 700 & 36.3 & 93.79 & 17.8 & 5.269 \\
\hline
\end{tabular}

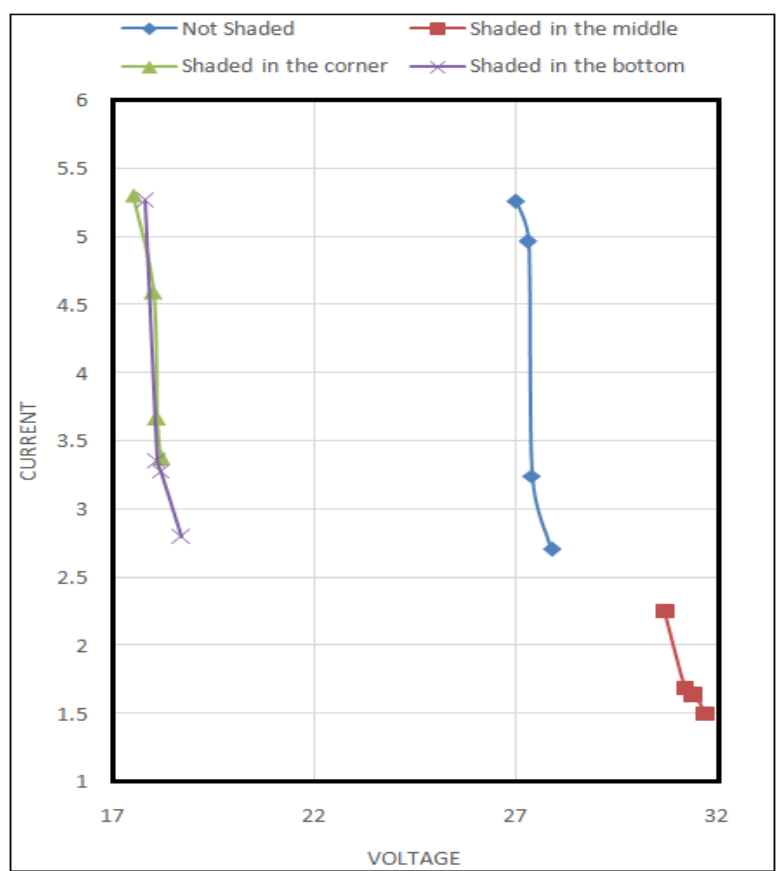

Figure 10. Effect of shading on the solar cell produces variation in current/voltage

Table 4. Power Output from Solar Cell on Different Humidity at Fixed Temperature [24-25]

\begin{tabular}{cccc}
\hline Humidity (\%) & Voltage $(\mathrm{V})$ & Current $(\mathrm{A})$ & Power $(\mathrm{W})$ \\
\hline 25 & 17.10 & 2.78 & 47.53 \\
30 & 16.72 & 2.63 & 43.97 \\
35 & 16.53 & 2.42 & 40.01 \\
40 & 16.45 & 2.30 & 37.60 \\
45 & 16.41 & 2.14 & 35.11 \\
50 & 16.33 & 2.04 & 33.31 \\
\hline
\end{tabular}

Table 5. Effect of Direction of the Solar Cell towards Sun on Different Angles

\begin{tabular}{|c|c|c|c|c|c|c|}
\hline Direction & E-S 450 & E-S 150 & $\mathrm{S} \mathrm{O}^{0}$ & S-W 150 & S-W 300 & S-W 450 \\
\hline$V_{m p}($ volts $)$ & 27.2 & 27 & 25.4 & 25.9 & 25.9 & 25.8 \\
\hline$I_{m p}(a m p)$ & 4.8 & 5.2 & 4.43 & 3.9 & 3.78 & 3.6 \\
\hline $\boldsymbol{V}_{o c}($ volts $)$ & 33 & 33.5 & 33.2 & 32.8 & 32.8 & 32.8 \\
\hline $\boldsymbol{I}_{\boldsymbol{s c}}(\mathrm{amp})$ & 6.84 & 6.32 & 4.95 & 4.45 & 4.33 & 3.98 \\
\hline
\end{tabular}

So, for the best result the PV module should be in the right direction and for this the Azimuth angle is calculated by the use of compass manually. The solar tracker is the other option which can be used to get the maximum sunlight all the time. Solar tracking system automatically tracks the maximum sunlight and sets the direction for the module.

\section{CONCLUSION}

Need of renewable energy resources in future would rely on demand of smooth electrical power from renewables as the fossils are on way to depletion. This would ultimately result in keeping the environment more clean and eco-friendly. Among all the renewable energy resources the solar energy has maximum potential to fulfil the demand. Comparison shows the superiority of mono crystalline over poly crystalline in terms of efficiency. There are some important factors which affects the performance of the PV system. Results shows that the significant effect of humidity, temperature, irradiation and shading on the performance of the PV system. Moreover, results showing the effect of the direction of the solar cells are more encouraging.It's further concluded, that in order to ensure smooth output from the PV Panel, the environmental factors are to be properly considered in order to neglect any hinderance in the power systems stability . 


\section{ACKNOWLEDGEMENTS}

The authors would like to acknowledge the facilities provided by North China Electric Power University for the accomplishment of this work and China Scholarship Council for their financial support.

\section{REFERENCES}

[1] A. Z. Adnan, M. E. Yusoff, H. Hashim. "Analysis on the Impact of Renewable Energy to Power System Fault Level”. Indonesian Journal of Electrical Engineering and Computer Science (IJEECS). 2018,11(2): 652-657.

[2] Energy Technology Perspectives 2012. Technical report, International Energy Agency (IEA), 2012. URL https://www.iea.org/publications/freepublications/publication/ETP2012_free.pdf. Accessed April 2017.

[3] Ellabban, Omar, Haitham Abu-Rub, and Frede Blaabjerg. "Renewable energy resources: Current status, future prospects and their enabling technology." Renewable and Sustainable Energy Reviews 39 (2014): 748-764.

[4] Spanggaard, H. and F.C. Krebs, A brief history of the development of organic and polymeric photovoltaics. Solar Energy Materials and Solar Cells, 2004. 83: p. 125-146.

[5] Baker, John. "New technology and possible advances in energy storage." Energy Policy 36, no. 12 (2008): 4368-4373.

[6] Angenendt, Georg, Sebastian Zurmühlen, Ramin Mir-Montazeri, Dirk Magnor, and Dirk Uwe Sauer. "Enhancing battery lifetime in PV battery home storage system using forecast based operating strategies." Energy Procedia 99 (2016): 80-88.

[7] Balcomb, J.D., Passive solar design handbook. 1983: American Solar Energy Society.

[8] Kreider, J.F. and F. Kreith, Solar heating and cooling: Active and passive design. 1982: Hemisphere Publishing Corporation.

[9] .Leva, S. and D. Zaninelli, Technical and financial analysis for hybrid photovoltaic power generation systems. WSEAS Transactions on Power Systems, 2006. 5(1): p. 831-838.

[10] Contino, R., S. Leva, and D. Zaninelli, Integrated renewable sources for supplying remote power systems. WSEAS Transactions on power systems, 2007. 2(2): p. 41-48.

[11] Yilmaz, S., et al., The analysis of different PV power systems for the determination of optimal PV panels and system installation-A case study in Kahramanmaras, Turkey. Renewable and Sustainable Energy Reviews, 2015. 52: p. $1015-1024$.

[12] Y. H. Sabri, W. Z. W. Hasan, S. Shafie, M. A. M. Radzi, A. H. Sabry. "Daily Harvested Energy of Cadmium Telluride Thin Film Photovoltaic". Indonesian Journal of Electrical Engineering and Computer Science (IJEECS). 2018, 11(1): 18-26.

[13] Panjwani, Manoj Kumar, and Ghous Bukshsh Narejo. "Effect of altitude on the efficiency of solar panel." International Journal of Engineering Research and General Science 2, no. 4 (2014)

[14] Panjwani, M. K. (2018). Solar Concentrator's Effect on Solar Panel Efficiency. Sukkur IBA Journal of Emerging Technologies, 1(1), 15-27.

[15] Bhol, R., et al. Environmental effect assessment on performance of solar PV panel. in Circuit, Power and Computing Technologies (ICCPCT), 2015 International Conference on. 2015. IEEE.

[16] Kumari, J.S. and C.S. Babu, Mathematical modeling and simulation of photovoltaic cell using Matlab-Simulink environment. International Journal of Electrical and Computer Engineering (IJECE), 2011. 2(1): p. 26-34.

[17] Khanna, V., B.K. Das, and D. Bisht, MATLAB/SIMELECTRONICS models based study of solar cells. International Journal of Renewable Energy Research (IJRER), 2013. 3(1): p. 30-34.

[18] Ahmad, T., S. Sobhan, and M.F. Nayan, Comparative analysis between single diode and double diode model of PV cell: Concentrate different parameters effect on its efficiency. Journal of Power and Energy Engineering, 2016. 4(03): p. 31.

[19] Hegedus, S. and A. Luque, Achievements and challenges of solar electricity from photovoltaics. Handbook of Photovoltaic Science and Engineering, Second Edition, 2011: p. 1-38.

[20] Mohammed, S.S., Modeling and Simulation of Photovoltaic module using MATLAB/Simulink. International Journal of Chemical and Environmental Engineering, 2011. 2(5).

[21] Ellabban, O., H. Abu-Rub, and F. Blaabjerg, Renewable energy resources: Current status, future prospects and their enabling technology. Renewable and Sustainable Energy Reviews, 2014. 39: p. 748-764.

[22] Z. Syafiqah, Y.M. Irwan, N.A.M Amin, W.Z. Leow, A.R. Amelia, M. Irwanto. "Thermal and Electrical Study for PV Panel with Cooling System". Indonesian Journal of Electrical Engineering and Computer Science (IJEECS). 2017, 7(2): 492-499

[23] Panjwani, Manoj Kumar, Li Meicheng, Danish Khan, Idris Khan, and Mohan Menghwar. "Effect of solar concentrators on the efficiency of solar panels." In 2018 International Conference on Computing, Mathematics and Engineering Technologies (iCoMET), pp. 1-7. IEEE, 2018.

[24] Panjwani, M.K. and Narejo, G.B., 2014. Effect of humidity on the efficiency of solar cell(photovoltaic). International Journal of Engineering Research and General Science, 2(4), pp.499-503.

[25] Panjwani, Manoj Kumar, Suresh Kumar Panjwani, Fareed Hussain Mangi, Danish Khan, and Li Meicheng. "Humid free efficient solar panel." In AIP Conference Proceedings, vol. 1884, no. 1, p. 020002. AIP Publishing, 2017. 